\title{
Effects of Augmented Reality in Teaching Old Turkish Language Mementoes on Student Achievement and Motivation
}

\author{
Nurullah Sahin \\ Sinop University, Turkey \\ ORCID: 0000-0002-3462-0369 \\ Mehmet Fatih Ozcan \\ Agri Ibrahim Cecen University, Turkey \\ ORCID: 0000-0002-0721-9422
}

\begin{abstract}
The Turkish history has a very rich content in literary context as well as political and administrative achievements. The Turkish language, which dates back to B.C., has become one of the great languages that continues its existence until modern day, leaving priceless reference guide behind. The purpose of this research is to investigate the effects of lessons taught using activities designed with Augmented Reality Technology on the academic achievement and motivation of students in the teaching of the subjects of Yusuf Has Hacib, Kasgarli Mahmud, Kutadgu Bilig and Divanu Lugati't-Turk which are among the cultural heritages called "Old Turkish Language Mementoes." In this context, Augmented Reality environments were designed in relation to the mentioned works and authors and these designs were uploaded to AURASMA 3D application and made available for smart phones. Quantitative research model was adapted in the study and the quasi-experimental method with pre-test-post-test control group was used. At the end of the study whose procedures took 6 weeks in total with the involvement of 50 college students, it was determined that AR activities has a positive effect on the academic success of the students and increases the academic success of the students, and it creates a positive environment which motivates the students towards the lesson and learning.
\end{abstract}

Keywords: Augmented reality; Educational technology; Old Turkish language mementoes; Academic achievement; Student motivation

\section{Introduction}

The most important characteristics that distinguish humans from other living creatures are that humans have the ability to think, to communicate and the fund of knowledge obtained through these. Language is, without doubt, the most important means that carries the culture and the human who lives dependent on the time and space just like other living creatures from today and present place to the past, future or to other places. As long as the language lives, it embodies all the concepts that the culture reaches with words and transfers them from generation to generation and it becomes the identity and the memory of each generation it reaches. Language, which is the conveyer of the creating power of the individual, shapes the individual, enhance him to its level and embodies him within itself. Individuals, who are alive but the changing 
CONTEMPORARY EDUCATIONAL TECHNOLOGY, 2019, 10(2), 198-213

DOI: hpps://doi.org/10.30935/cet.5544501 - TYPE: Research Article

transporter of the language, carry the language to the future by developing the culture and the language with their creativity.

Literary works in which the expression power of language is used with its all aspects also carry the information such as language characteristics, sociocultural structure of the era to the future along with the literary characteristics of the author. In this context, it is important for our young generation to know these works which represent the eras they were written in the Turkish cultural history and carry these to modern-day. The development of the innovative technologies helps instructional designers develop learning environments which facilitate learning (Chang, $\mathrm{Hsu}$ and $\mathrm{Wu}, 2016)$. The rapid and widespread use of wireless networks and mobile devices has facilitated access to innovative technologies such as Augmented Reality (AR) and provides significant advantages for technology-supported learning (Ozdemir, 2017).

With the rapid change in information technologies and the increase in the usage of mobile technologies, visual technology content is gaining importance. Mobile devices are becoming increasingly popular and the mobile application demands desired by people of different age groups have led to an increase in the quality and quantity of applications running on mobile devices (Bekleyen \& Yilmaz, 2012; Kukulska-Hulme \& Shield, 2008). In this way, the application libraries working on mobile devices have become much richer.

The use of Augmented Reality Technologies (ART), which has been developed to enrich education and training environments and ensure lasting learning, is becoming increasingly popular. Augmented Reality (AR) is a new technology which is an interactive experience of a real-world environment whereby the objects that reside in the real-world are "augmented" by computer-generated perceptual information, sometimes across multiple sensory modalities, including visual, auditory, haptic and somatosensory, and so it alters one's ongoing perception of a real-world environment. The reason for the augmented reality has gained importance is the fact that an object can be presented as a three-dimensional process in a computer environment. However, both the augmented reality app and the fact that this app is on a mobile platform is more advantageous in terms of both usability and attractiveness compared to presenting it in virtual environments. Augmented reality technology is important in terms of bringing objects which are difficult to imagine and think into an imaginable and thinkable structure and associating it with the real world.

Augmented reality defined as technology that allows simultaneous enrichment of real-world events with virtual data (Azuma, 1999) comes to the forefront with its features that enrich existing media reality with objects added to the virtual environment (Kerawalla, Luckin, Seljeflot \& Woolard, 2006) and making them dynamic (Cheng \& Tsai, 2013). These features provide ART users with more information and perception than normal conditions (Sarikaya \& Seferoglu, 2016).

Thanks to the ever-evolving technology, AR has now become available for use on computers or mobile devices without requiring special equipment. Therefore, the use of AR technologies is also rapidly developing. It is seen that $A R$ technologies are used in a wide range from tourism to military areas, from advertising to health (Yen, Tsai, \& Wu, 2013). It can be said that the biggest effect of ART applications to be widespread is the widespread use of mobile devices (Sarikaya \& Alsancak Sarikaya, 2018). The use of mobile devices in AR applications and the reduction of the need for special equipment have also made ART available in the field of education ( $\mathrm{Wu}$, Lee, Chang, \& Liang, 2013). As a result of the use of ART in the field of education, the use of ART for educational purposes has become one of the research topics of educational scientists. When 
the conducted studies are examined, it is seen that there are many advantages of using ART in the field of education. These advantages are that it increases the student success (Cai, Wang, \& Chiang, 2014; Chen \& Wang, 2015; Hsiao, Chen, \& Huang, 2012; Hwang, Wu, Chen, \& Tu, 2016; Shelton \& Hedley, 2002; Sirakaya, 2015; Vilkoniene, 2009; Zhang, Sung, Hou, \& Chang, 2014), it encourages live and learn (Singhal, Bagga, Goyal, \& Saxena, 2012), it supports learning by questioning (Chiang, Yang, \& Hwang, 2014; Squire \& Jan, 2007; Wang, Duh, Li, Lin, \& Tsai, 2014). It is also seen that it increases the participation of the students in the class (Delello, 2014; Dunleavy, Dede, \& Mitchell, 2009), their motivation (Chiang et al., 2014; Furió, Juan, Segui, \& Vivó, 2015; Perez-Lopez \& Contero, 2013; Solak \& Cakir, 2015) and makes the classes more fun. Moreover, it supports conceptual learning (Abdusselam, 2014; Enyedy, Danish, Delacruz, \& Kumar, 2012; Kerawalla et al., 2006) and it eliminates the misconception of the students (Rosenbaum, Klopfer, \& Perry, 2006; Sirakaya, 2015; Tian, Endo, Urata, Mouri, \& Yasuda, 2014). Thanks to these advantages, it can be said that AR is a useful tool in different areas of education.

Today's students are educated in a way that they are prone to the technologies of the digital age. In this way, students have a high level of readiness at the point of using ART. This suggests that educators should include ART applications in the classroom. In this respect, the aim of this study is to determine the effect of ART use in transferring our past to the future on students' academic success and the effect of ART applications on students' motivation. In the direction of this purpose, the sub-problems of the study are determined as follows:

1. Is there a significant difference between the academic achievement levels of the experimental and control groups regarding Yusuf Has Hacib, Kasgarli Mahmud, Kutadgu Bilig and Divanu Lugati't-Turk subjects before starting experimental process?

2. Is there a significant difference between the academic achievement levels of the experimental and control groups regarding Yusuf Has Hacib, Kasgarli Mahmud, Kutadgu Bilig and Divanu Lugati't-Turk subjects after the experimental process?

3. Is there a significant difference between the academic achievement scores of the experimental group before and after the experimental procedures?

4. What are the motivation levels of the experimental group students against the applications developed with ART?

\section{Research on Augmented Reality}

When reviewing the studies about ART (Augmented Reality Technology) in Turkey and in the world, we can see many studies in different fields of science. In general, subjects such as the importance of ART, areas of its use, integration into educational environment, mobile augmented reality applications and integration into educational environments, effects of ART on students' academic achievement etc. are the subject areas that are compatible with the area of interest of the present study. We can show the following studies about the use of ART in educational environments and the benefits it provides as an example.

Abdusselam and Karal (2012) designed an augmented reality environment for the teaching of the subject "Magnetism" in physics lesson and examined the effect of this use of media on students' academic achievement. As a result of the research conducted as an experimental study with the pre-test post-test control group, the results were in favor of the experimental group. Therefore, the students have a favorable opinion about augmented reality environments and AR environments provide an advantage in increasing the students' success in the physics course. 
In their study, Cetinkaya and Akcay (2013) emphasized the application of augmented reality practice in educational environments and emphasized the effect of augmented reality on teaching and learning. As a result of the study, it has been concluded that augmented reality practices constitute a great richness in the dimensions of educational activities such as curriculum, guidance and introduction, games, educational trips and exercise.

Ibili and Sahin (2013) developed a software called ARGE3D which can be used in desktop computers in order to display two dimensional (2D) static images as 3D images on computer screen within geometric objects subject of the 6th grade mathematics lesson.

In their study on augmented reality in English learning conducted with $1225^{\text {th }}$ grade students from 5 different schools in Erzurum province of Turkey, Kucuk, Yilmaz, and Goktas (2014) concluded that students were eager to use augmented reality technologies and that their anxiety levels were low when using this technology.

In their studies titled as "Investigation and Evaluation of Mobile Augmented Reality Applications Educationally" in 2015, Demirer and Erbas (2015) conducted an investigation on AR applications and evaluated them from an educational perspective. Based on the result of their evaluation, they suggested the use of mobile ART applications in educational environment. Accordingly, researchers made conclusions and recommendations at the end of the study that mobile augmented reality applications should be used effectively in educational process, applications will facilitate learning in both science and social fields, these practices will enrich the content of the course and make the lesson fun; that is why further studies are needed to increase the use of such practices and address their effectiveness.

Arslan and Elibol (2015) examined the first 100 educational augmented reality applications developed for mobile devices and listed on Google Play from various perspectives. In this study, whose aim was to examine the educational augmented reality applications developed for mobile devices, the first 100 applications listed by the number of downloads in the Google Play Market are evaluated in terms of criteria such as whether they carry augmented reality features, the category of market they are published, the distribution of the topics covered, the area they worked, the last updated dates and the number of downloads. Following the evaluations, 18 applications which are noteworthy, and which are considered to be important for education were examined and introduced in detail.

Icten and Bal (2017) examined 34 academic studies on the augmented reality technology conducted between 2010-2016 with content analysis method in nine categories. With this study, the researchers aimed to examine the augmented reality studies at the academic level in a way to include the software and hardware features that they have, and to reveal their tendencies. In the study in which the publication years of the studies, the magazines or books, the augmented reality (AR) pointer usage type, the type of imaging system, the distribution of spatial imaging systems, the distribution of portable imaging systems, the distribution of head-mounted imaging systems (HMD), the user and the device interaction method, the data of the distribution of augmented reality tools (fireworks) were analyzed, it was determined that the number of studies conducted in the AR field between the years 2010-2016 is close to each other, mostly pointer-based AR technology is used by researchers in the studies (82\%), video-based systems (94\%) are used more than optical-based systems (6\%), it has user-application interaction is predominantly made with touch or mouse, ARToolKit tool is the more preferred tool in creating the environments (41\%). 
CONTEMPORARY EDUCATIONAL TECHNOLOGY, 2019, 10(2), 198-213

DOI: hpps://doi.org/10.30935/cet.5544501 - TYPE: Research Article

Ozcan, Ozkan and Sahin (2017) conducted an experimental study on the effects of using augmented reality applications in Ottoman Turkish readings on student performance. The sample of the study consisted of 60 students, 30 in experimental group and 30 in control group, all from the Department of Turkish Language Teaching at Agri Ibrahim Cecen University. According to the findings of the study, it was observed that the use of ART in Ottoman Turkish readings increased academic success and satisfaction of the students.

Yilmaz and Batdi (2016) analyzed the data of 12 studies in the national and international area in order to determine the effect size of augmented reality applications on academic achievement within the framework of a meta-analysis. They found that the effect of augmented reality applications on student success was low; however, these practices have positive effects on students' social, cognitive, and affective development and make the learning environment more realistic. This meta-analysis is important in terms of combining the results of 12 different studies. The results of this study are interpreted as a combined impact of the experimental studies about ART. Therefore, generalization of the results obtained from these results is higher than that of individual studies.

Other studies can be listed in addition to these studies. However, the above-mentioned research was found to be sufficient in terms of showing the positive effect of using ART in educational environments. The common result of these studies is the inevitable benefit and effect of ART in the education process. ART-supported educational environments have a positive effect not only on the academic performance of students but also on their attitudes towards the lessons and learning in general. On the other hand, one of the most important benefits of ART in the educational process is that it reduces the factors that negatively affect learning such as anxiety, and stress and makes the education fun.

Results of the studies regarding the use of ART in language teaching are of particular importance. When the literature is reviewed, it is seen that there are very few studies on the use of ART in language teaching. In particular, there are no studies investigating the results of using ART in the introduction and teaching of the basic sources of Turkish. More importantly, there are almost no experimental studies on the use of technology in the teaching of these resources which are of great importance in terms of Turkish language and literature. Due to this, in this study, the basic resources of Turkish, which provide fundamental information on the Turkish culture and values and undertake an important mission in carrying the Turkish culture to the future, the effects of ART on better introduction and teaching of the young generations were investigated. In this respect, this study is a pioneer in the literature and it is thought to shed some light on the following studies to be done in this context.

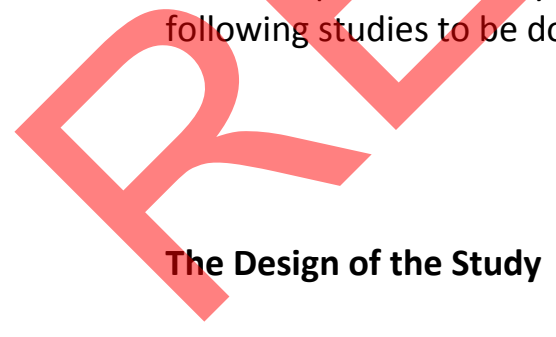

In this study in which the effects of lessons taught using activities designed with AR technology on the academic success and motivation of the students in the teaching of the subjects of Yusuf Has Hacib, Kasgarli Mahmud, Kutadgu Bilig and Divanu Lugati't-Turk which are among the Turkish cultural heritages called "Old Turkish Language Mementoes", quasi-structured experimental design with pre-test-post-test control group (paired) was used. In the quasi- 
experimental design used in cases where the groups are not randomly selected, two of the groups are tried to be matched on certain variables and which group will be experimental group and which will be the control group is decided by a random assignment (Buyukozturk, 2007; Karasar, 2003).

\section{Study Group}

The study was carried out with 50 students studying at the Department of Turkish Language Education in the Faculty of Education of Agri Ibrahim Cecen University during the fall semester of 2017-2018 academic year. The students were divided into two groups as 25 experimental and 25 control groups. The distribution of students by gender variable is indicated in Table 1.

Table 1. Distribution of Research Group by Gender Variables

\begin{tabular}{lccccc}
\hline Gender & \multicolumn{3}{c}{ Experimental } & & Control \\
\cline { 2 - 5 } & $\mathbf{f}$ & $\%$ & 10 & $\%$ \\
\hline Female & 12 & 48 & 15 & 40 \\
\hline Male & 13 & 52 & 25 & 60 \\
\hline Total & 25 & 100 & 100 \\
\hline
\end{tabular}

\section{Data Collection Tools}

\section{Academic Achievement Test}

An academic performance test including 20 multiple-choice and 10 fill-in-the-blank type questions related to the subjects of Yusuf Has Hacib, Kasgarlı Mahmud, Kutadgu Bilig and Divanu Lugati't-Turk, which were taught to experimental and control groups during the lessons, were prepared to determine the academic performance of the students. In developing the academic achievement test, first two researchers prepared questions related to the subject. Afterwards, two researchers came together to discuss the questions they prepared and formed a common draft. The draft was sent to two field experts and two language experts for their evaluation. In accordance with the feedback from the experts, the necessary revisions were made on the draft test and put it into final form. In order to test the reliability of the test, the pilot scheme was carried out. In this context, the academic achievement test, which was formed by taking expert opinions, was applied to 33 students studying in the Department of Turkish Language Teaching at Faculty of Education, Agri Ibrahim Cecen University. The collected data were subjected to reliability analysis in IBM SPSS Statistic package program. As a result of the analysis, the reliability coefficient was found to be .78. This value shows that the test has a good level of reliability. The academic achievement test was applied to the experimental and control groups at the beginning of the study both as a pretest and as a posttest at the end of the study.

\section{Instructional Materials Motivation Survey}

It was used to determine the motivation levels of the students related to the designs prepared with AR technology about the subjects of Yusuf Has Hacib, Kasgarli Mahmud, Kutadgu Bilig and Divanu Lugati't-Turk under the main theme of "Old Turkish Language Mementoes." Instructional materials motivation survey which was developed by Keller (1987) was adapted to Turkish by 
Kutu and Sozbilir (2011) and its reliability and validity studies were conducted. According to this study, the survey consists of 24 items with a two-factor structure (attention-compliance and confidence-satisfaction). The reliability coefficient of the survey (Cronbach Alpha) was 0,83 for the total survey; for sub-factors 0.79 and 0.69 , respectively. The survey was prepared as 5 -point Likert scale and graded as "Strongly Disagree (1)", "Slightly Agree (2)", "Agree (3)", "Mostly Agree (4)" and "Strongly Agree (5)."

\section{ART Instructional Material}

During the experimental process, the materials used in the lessons taught to the experimental group were developed by the researchers. First, research on the subjects to be taught in the lessons was done and scenarios were planned regarding the order of the information to be taught. These mentioned scenarios were prepared by two faculty members with PhD. Then the pictures and animations that are suitable for the content of the scenarios are drawn by the experts. A total of 4 activities -one of which were related to each topic- were designed by the researchers. Students were able to view the design of the relevant activity when they read the QR codes previously distributed to them via the AURASMA 3D app, which was preinstalled on their smartphones. Some visuals of the designs created with ART are presented below.

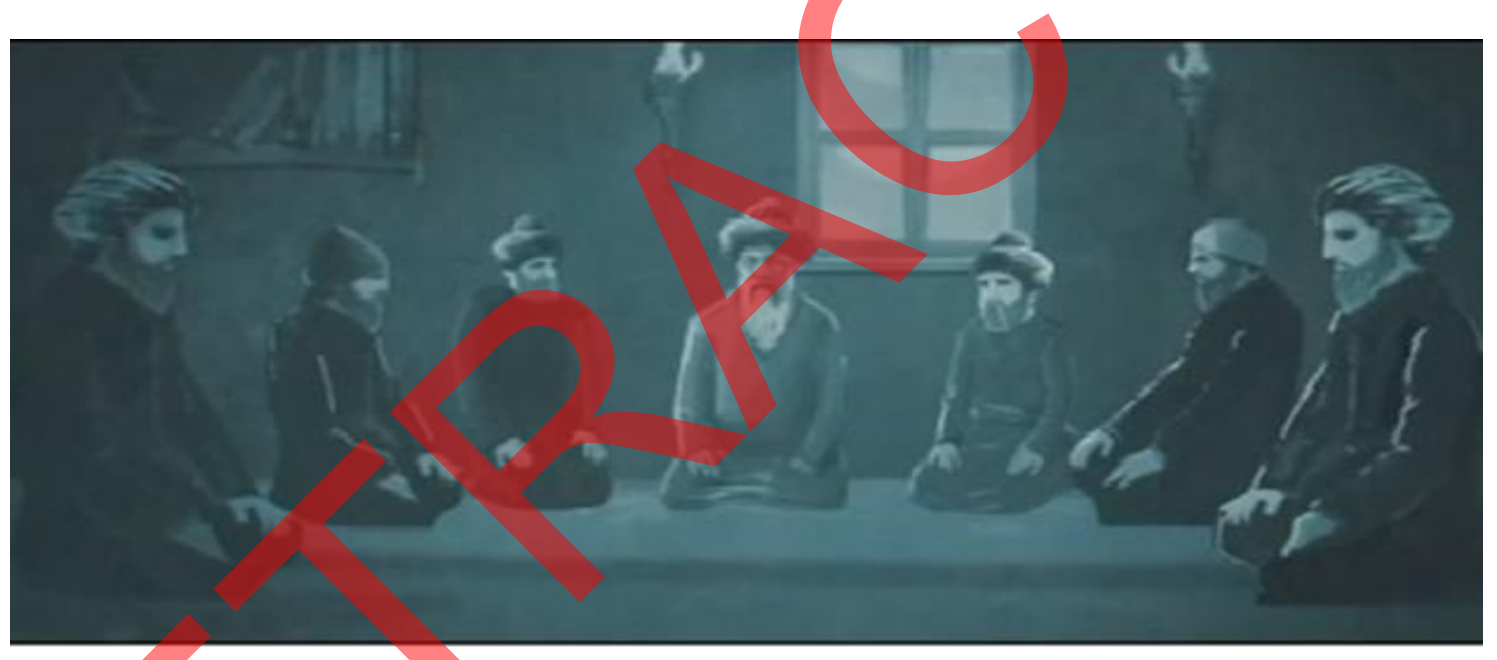

Figure1. An Image of Yusuf Has Hacib Depicted in Conversation

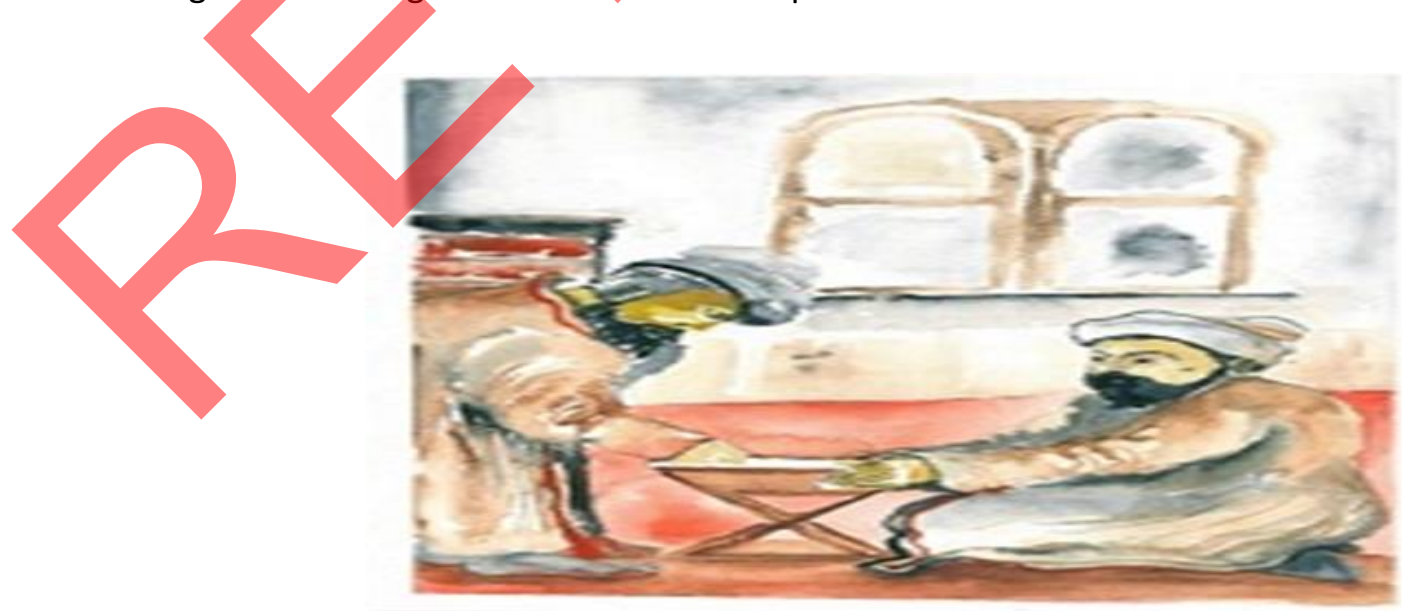

Figure 2. An Image of Kasgarli Mahmud Depicted While Teaching in the Madrasa 


\section{Application Process}

In this study, it is aimed to investigate the effects of lessons taught using activities designed with AR technology on the academic achievement and motivation of students in the teaching of the subjects of Yusuf Has Hacib, Kasgarli Mahmud, Kutadgu Bilig and Divanu Lugati't-Turk which are among "Old Turkish Language Mementoes." In this context, ART-generated materials were used in the lessons with the experimental group, whereas in the lessons in the control group, classical course materials (lecture notes, books etc.) were used. Application process took a total of 6 weeks (24 class hours) as teaching the subject of Yusuf Has Hacib (1 week), Kutadgu Bilig (1 week), Kasgarli Mahmud (1 week), Divanu Lugati't-Turk (1 week), application of pretest and posttest and instructional materials motivation survey ( 2 weeks).

In the lessons taught to the control group, the teacher of the course conducted the lectures with the presentation technique. In this context, when the teacher entered the classroom, he started making routine lesson preparations (taking the register, preparing students for the lesson etc.) and started to explain the subject of that day. While the teacher was teaching, the students listened to the teacher, noted the important points, and followed the lesson from the required sources.

In the lessons that were conducted with the experimental group, the teacher of the course also continued the lessons by using the presentation technique. The students in the experimental group also used ART materials prepared by the researchers as well as other course materials in the follow-up of the course. The teacher in the experimental group started to explain the subject of the course after completing the routine course preparation. In addition to the activities of the students in the control group during the course of the lesson, the students in the experimental group reached the ART materials prepared on the subject by scanning the QR codes given to them in advance by using their mobile devices when necessary. ART materials contained images and animations related to the subject. These visuals and animations were important for students to embody the subject and to achieve permanent learning. The students, who reinforced the subject of the course by following the ART material designed by the researchers, then shared their ideas, learning and deductions with their classmates. After the students exchanged ideas, the teacher completed the lesson.

Table 2. The Application Process of the Study

\begin{tabular}{|c|c|c|}
\hline Week & Control Group & Experimental Group \\
\hline & $\begin{array}{l}\text { The academic achievement test } \\
\text { prepared by the researchers was used } \\
\text { as a pretest to determine the } \\
\text { academic level of the students. }\end{array}$ & $\begin{array}{l}\text { - The academic achievement test prepared by the } \\
\text { researchers was used as a pretest to determine } \\
\text { the academic level of the students. } \\
\text { - Students were provided with the download of } \\
\text { the Aurasma AG app to their smartphones and } \\
\text { explained how to use it. }\end{array}$ \\
\hline & $\begin{array}{l}\text { - Traditional direct instruction method } \\
\text { was used to teach the subjects } \\
\text { related to Yusuf Has Hacib. } \\
\text { - Students were provided to follow the } \\
\text { lessons from the notes prepared. }\end{array}$ & $\begin{array}{l}\text { - ART was used to teach the subjects related to } \\
\text { Yusuf Has Hacib. } \\
\text { - The students were provided with the } \\
\text { opportunity to follow the lessons from the } \\
\text { designs created by using ART. }\end{array}$ \\
\hline 3 & $\begin{array}{l}\text { - Traditional direct instruction method } \\
\text { was used to teach the subjects } \\
\text { related to Kutadgu Bilig. }\end{array}$ & $\begin{array}{l}\text { - ART was used to teach the subjects related to } \\
\text { Kutadgu Bilig. }\end{array}$ \\
\hline
\end{tabular}




\begin{tabular}{|c|c|c|}
\hline & $\begin{array}{l}\text { - Students were provided to follow the } \\
\text { lessons from the notes prepared. }\end{array}$ & $\begin{array}{l}\text { - The students were provided with the } \\
\text { opportunity to follow the lessons from the } \\
\text { designs created by using ART. }\end{array}$ \\
\hline 4 & $\begin{array}{l}\text { - Traditional direct instruction method } \\
\text { was used to teach the subjects } \\
\text { related to Kasgarli Mahmud. } \\
\text { - Students were provided to follow the } \\
\text { lessons from the notes prepared. }\end{array}$ & $\begin{array}{l}\text { - ART was used to teach the subjects related to } \\
\text { Kasgarli Mahmud. } \\
\text { - The students were provided with the } \\
\text { opportunity to follow the lessons from the } \\
\text { designs created by using ART. }\end{array}$ \\
\hline 5 & $\begin{array}{l}\text { - Traditional direct instruction method } \\
\text { was used to teach the subjects } \\
\text { related to Divanu Lugati't-Turk. } \\
\text { - Students were provided to follow the } \\
\text { lessons from the notes prepared. }\end{array}$ & $\begin{array}{l}\text { - ART was used to teach the subjects related to } \\
\text { Divanu Lugati't-Turk. } \\
\text { - The students were provided with the } \\
\text { opportunity to follow the lessons from the } \\
\text { designs created by using ART. }\end{array}$ \\
\hline 6 & $\begin{array}{l}\text { - The academic performance test } \\
\text { prepared by the researchers to } \\
\text { determine the achievement level of } \\
\text { the students as a result of the lessons } \\
\text { learned through traditional } \\
\text { instruction method has been applied } \\
\text { as a posttest. }\end{array}$ & $\begin{array}{l}\text { - The academic performance test prepared by the } \\
\text { researchers was used as a posttest in order to } \\
\text { determine the achievement level of the } \\
\text { students. } \\
\text { - Instructional Material Motivation Survey was } \\
\text { applied to determine how the use of ART affects } \\
\text { students' motivation. }\end{array}$ \\
\hline
\end{tabular}

\section{Analysis of the Data}

The research is an experimental study with a control group. The research group consisted of 50 students, 25 in the experimental group and 25 in the control group. Due to the fact that the number of students in the experimental and control groups is below 30, such research groups are considered as small-scale sample groups according to the current literature. Therefore, it is recommended to perform non-parametric tests in the analysis of data belonging to such sample groups (Cil, 2008; Akturk \& Acemoglu, 2011; Kartal, 2006). However, when the current literature is examined, it is seen that there are also researchers with different opinions on this subject. Buyukozturk (2013) states:

The size of the samples, which are the data source of the research, also affect the choice of statistics. It can be assumed that the data collected over large groups are distributed close to the normal distribution and the corresponding statistics can be selected. However, for example, it is difficult to assume that the scores are normally distributed when the number of groups falls below 15 or 30 according to some. It is stated that non-parametric statistics should be used when the number of groups decreases to six. In the literature, however, it is observed that the researchers carrying out small group experimental studies use parametric statistics if the distribution of the data they collect is appropriate (p. 150).

Concerning the subject, Armutlulu (2008) stated that the distribution of the population in the studies with sample groups of less than 30 was on the agenda, and that if the population is assumed to have a normal distribution in such studies, then parametric tests can be used (Armutlulu, 2008). Similarly, Levine, Ramsey and Smidt stated that samples larger than 30 were normally distributed, samples larger than 15 were approximately normally distributed, and that if the population had a normal distribution, then normal distribution could be discussed without considering the sample, and parametric test could be employed (Levine, Ramsey, \& Smidt, 2001). 
In the light of this information, normality test was applied to test whether the experimental and control groups used in the present study showed normal distribution. As a result of the normality test, experimental and control groups showed a normal distribution $(p=.972, p>.05)$.

Regarding this issue, de Winter (2013) stated that even though the researchers who conduct experimental studies with extremely small sample groups $(N \leq 5)$, parametric tests can be used if the effect size of the study is high. As a result of the calculations, the effect size of this study was calculated as .23. This value indicates a high effect, taking into account the Cohen's $d$ criteria $(.01=$ low impact, $.06=$ medium effect and $.14=$ high impact) (Cohen 1988 cited in Pallant (2016).

Since parametric tests have a greater statistical power and are more effective in detecting an existing difference (Balci, 2006; Basturk, 2011; Ozdamar, 2002; Ozdamar, 2003; Kartal, 2006), it was decided to use parametric tests while analyzing the data in the study. In this context, while using the independent $\mathrm{t}$-test, one of the parametric tests, to test whether the difference between the experimental and control groups is significant, dependent sample t-test was used to determine whether there was a significant difference between the pretest and posttest results of the experimental group.

\section{Findings Related to the First Research Question of the Study}

An answer to the question "Is there a significant difference between academic achievement levels of the experimental and control groups regarding Yusuf Has Hacib, Kasgarli Mahmud, Kutadgu Bilig and Divanu Lugati't-Turk before starting experimental process?" was sought, and the findings related to the pretest results of both groups are indicated in Table 3.

Table 3. Independent Sample t-test Results of Academic Performance Pretest of Experimental and Control Groups

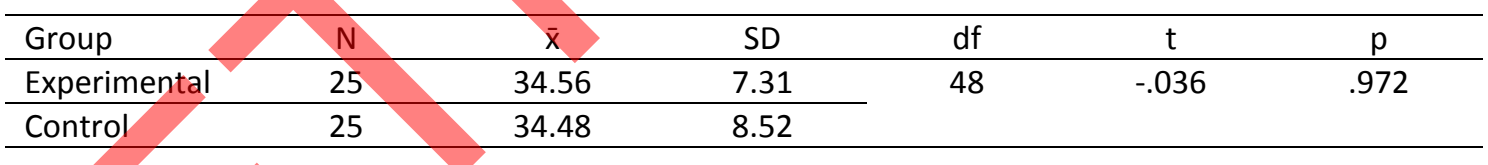

When Table 3 is examined, it is seen that there is no significant difference between the experimental and control groups related to academic success pretest means $(p>05)$. The pretest means of the experimental group were 34.56 and the pre-test averages of the control group were 34.48. The difference between the two groups was not statistically significant. In other words, this situation can be expressed that the experimental and control groups were equal to each other in terms of academic achievement before the application.

\section{Findings Related to the Second Research Question of the Study}

The results of the academic achievement posttest of the experimental and control groups were analyzed by independent sample t-test to answer the question "Is there a significant difference between academic achievement levels of the experimental and control groups regarding Yusuf 
CONTEMPORARY EDUCATIONAL TECHNOLOGY, 2019, 10(2), 198-213

DOI: hpps://doi.org/10.30935/cet.5544501 - TYPE: Research Article

Has Hacib, Kasgarli Mahmud, Kutadgu Bilig and Divanu Lugati't-Turk subjects after the experimental process?" The results obtained from the related analysis are indicated in Table 4.

Table 4. Test and Control Groups' Posttest Independent Sample t-test Results

\begin{tabular}{|c|c|c|c|c|c|c|c|}
\hline Group & $\mathrm{N}$ & $\bar{x}$ & SD & df & $\mathrm{t}$ & $\mathrm{p}$ & $r$ \\
\hline Experimental & 25 & 66.08 & 10.83 & 48 & -3.82 & .000 & .23 \\
\hline Control & 25 & 52.48 & 14.12 & & & & \\
\hline
\end{tabular}

When Table 4 is examined, it is obvious that there is a significant difference between the experimental and control groups' academic achievement posttest means in favor of the experimental group. After the experimental process, the arithmetic mean of the experimental group was calculated as 66.08 and the arithmetic mean of the control group was calculated as 52.48. These results show that the lessons taught by using ART have a significant difference on the academic achievement of the students compared to the lessons taught by using the traditional direct instruction method ( $p>05)$. In other words, this situation can be expressed that using ART in teaching the subjects of Yusuf Has Hacib, Kasgarli Mahmud, Kutadgu Bilig and Divanu Lugati't-Turk is more effective on students' academic achievement. When Table 4 is further examined, it is seen that the $r$ value showing the effect size of the study is calculated as .23. This value indicates that the study has a high effect; that is, the results are high as far as generalizability is corned. According to this finding, it can be said that the results of the study are at a good level in terms of representing the population.

\section{Findings Related to the Third Research Question of the Study}

The third research question of the study is expressed as "Is there a significant difference between the academic achievement scores of the experimental group before and after the experimental procedures?" In this context, the pre-test and post-test academic achievement scores of the experimental group were analyzed with the dependent sample $t$ test and the results are indicated in Table 5 .

Table 5. Dependent Sample t-test Results of Academic Performance Pretest and Posttest Averages of the Experimental Group

\begin{tabular}{|c|c|c|c|c|c|}
\hline Application & $\mathrm{N}$ & $\bar{x}$ & $\mathrm{t}$ & $d f$ & $p$ \\
\hline Pre-Test & 25 & 34.56 & 23.62 & 24 & .000 \\
\hline Post-Test & 25 & 66.08 & 30.48 & & \\
\hline
\end{tabular}

When Table 5 is examined, it is seen that there is a significant difference between the average scores of the pre-test and post-test scores of the experimental group in favor of the post-test. While the average of pretest scores in the experimental group to whom the lessons were taught using ART was 34.56, the average of the post-test score was 66.08 . The difference between the two tests was statistically significant $(p>.05)$. It can be said that this difference is in favor of the post-test because the average of the posttest score is higher than the pre-test average. These results show that using ART in teaching the subjects of Yusuf Has Hacib, Kasgarli Mahmud, Kutadgu Bilig and Divanu Lugati't-Turk increased the academic achievement of students. 


\section{Findings Related to the Fourth Research Question of the Study}

The fourth sub-problem of the study is expressed as "What are the motivation levels of experimental group students against the applications developed with ART?" In this context, Instructional Material Motivation Survey developed by Keller (1987) was applied to experimental group students according to ARCS motivation model. According to the results of the survey, it can be said that the effects of the designs developed with ART on the students' motivations are positively high.

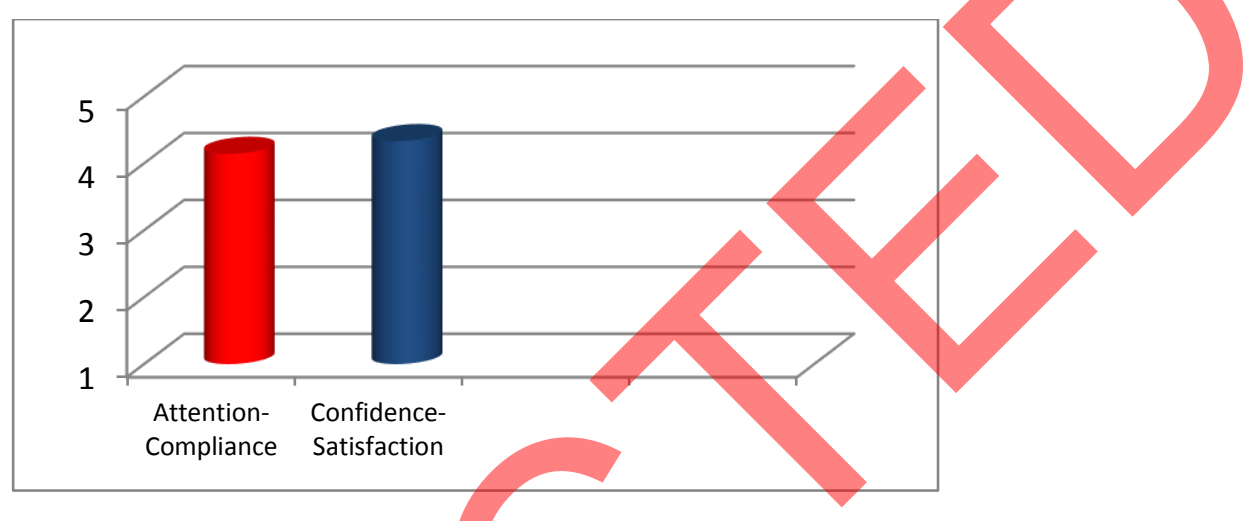

Figure 3. The Results of the Effects of Materials Prepared with Augmented Reality Technology on Students' Motivations in Terms of Sub-Dimensions

As seen in the Graph 1, when the mean of the dimensions of the material motivation survey is examined, it is seen that the attention-compliance dimension has the average of $(\bar{X}=4.14)$ and the confidence-satisfaction dimension has the average of $(\bar{X}=4.33)$. These results indicate that the material used is highly efficient. In other words, the developed materials have contributed positively to the students' motivation, their willingness to learn and the permanency of learning.

\section{Results and Recommendations}

This study investigated the effects of lessons taught using activities designed with AR technology on the academic success and motivation of the students in the teaching of the subjects of Yusuf Has Hacib, Kasgarli Mahmud, Kutadgu Bilig and Divanu Lugati't-Turk which are among the cultural heritages called "Old Turkish Language Mementoes."

According to the results, it was concluded that the lessons that were taught with the designs created with ART increased the academic performance of students. When the related literature is examined, it is possible to see the results of other studies that are parallel with this result. For example, El Sayed, Zayed and Sharawy (2011) concluded that augmented reality learning cards have a positive effect on students towards content. Juan, Llop and Abad (2010) concluded that augmented reality is useful in teaching vocabulary. Other studies which also concluded that the use of ART increases students' academic achievement can be listed as; Chen and Tsai (2012); Gavish et al. (2015); Han, Jo, Hyun, and So (2015); Huang, Chen, and Chu (2016); Ibanez, Serio, Villaran, and Kloos (2014); Kamaraine et al. (2013); Ke and Hsu (2015); Lin, Duh, Li, Wang, and Tsai (2013); Lin, Chen, and Chang (2013); Liou, Bhagat, and Chang (2016); Sommerauer and Muller (2014); Yang and Liao (2014); Zhang, Sung, Hou, and Chang (2014); Ozcan, Ozkan, and Sahin (2017). The use of ART in all the studies mentioned above had a positive impact on students' achievement in different courses, levels and samples. The fact that using ART 
addresses students' multiple sensory organs, embodies the abstract (Tulu and Yilmaz, 2012), simplifies what is difficult to understand (Demirer \& Erbas, 2015; Ibili \& Sahin, 2013), makes educational activities funnier (Cetinkaya \& Akcay, 2013; Demirer \& Erbas, 2015; Tulu \& Yilmaz, 2012), creates an environment in which there is more interaction (Cetinkaya \& Akcay, 2013; Kucuk, Yilmaz, \& Goktas, 2014; Yilmaz \& Batdi, 2016), makes the students active and requires working in harmony with science and technology (Polatcan, 2015) explains this situation. Although the results obtained from this study and the other studies draw attention to the positive effect of ART on the educational environment, it can be said that we still don't benefit from ART in the classes adequately. The main reason about the inability to utilize technology and its products in teaching and learning environment in Turkey is the unconsciousness of students and teachers who are one of the most important dynamics of teaching and learning activities. Another reason is the technological impossibilities in the schools and classes. Although all of these disadvantages have social, individual, political, economic etc. dimensions, it is important for the future of the Turkish education system that everyone should take full responsibility. The results of the other studies in the literature conducted in this context like the present study will be much more meaningful if we gain the consciousness and the effort to develop the education system as an individual and society.

Another result of the study is high motivation of the students towards the designs with ART that are used in the teaching of the lessons. Similar results can be found in other studies in the literature. Cakir, Solak, and Tan (2015), Pérez-López and Contero (2013), Mahadzi and Phung (2013) emphasized high motivation of the students towards ART-generated materials in their studies. This positive effect of ART-based course materials on student motivation has been prominent so much that it cannot be ignored in educational activities and scientific research have been taken their place in the literature. Today, one of the biggest problems of teachers in the classroom in Turkey, is that they have difficulty in keeping the attention and the motivation of students fresh. Many students find the lessons boring and have great difficulty in keeping their attention for a long time. This situation is not only a problem experienced by Turkish students, but also as a common problem of students around the world. In order to solve this problem, which harms the educational process, our greatest helper can be the technological applications such as ART and the activities in which the lessons are handled by using these applications. As a matter of fact, the results obtained from other studies given above, like the current study, show us the importance of such applications on the scientific level.

The present study, which uses scales and questionnaires as data collection tools, limits the scope and validity of the data obtained. For this reason, in order to obtain richer and in-depth data about the effectiveness of teaching activities carried out with ART, research should be carried out using scales and surveys as well as interview and observation methods. Comparing the results obtained from the studies carried out with qualitative data collection tools and the results coming from quantitative studies such as this study is important in terms of keeping it in perspective.

It has been observed that students' understanding is developed in a positive way with the educational materials in the current study, which are prepared both for the present and future students, to know the works/writers who are considered as Old Turkish Language Mementoes better and closer. The data obtained from this study is limited to the study group and the determined works/authors. For this reason, such technological and contemporary educational materials should be prepared for different resources of Turkish language, Turkish culture and Turkish history and the effectiveness of these materials should be tested with different sample groups. Especially in modern Turkey where there's a very intense cultural imperialism and 
disappearing of national values, technological designs including such people and works that have stamped on the Turkish civilization, culture, literature and history will undertake the transfer of culture and on the other hand will be recorded as a unique service to Turkish civilization. As a matter of fact, the applications and products designed in this context are scarce.

Finally, ART materials related to Turkish language, Turkish culture and Turkish history can be used not only by students and teachers in educational activities but also by other people who upload the related application to their mobile device. In this way, an awareness can be created in the community to protect the cultural heritage and community education activities can be spread to a wider ground.

\section{References}

Abdusselam, M. S. \& Karal, H. (2012). Fizik ogretiminde artirilmis gerceklik ortamlarinin ogrenci akademik basarisi uzerine etkisi: 11. sinif manyetizma konusu. Egitim ve Ogretim Araştirmalari Dergisi, 1(4), 170-182.

Akturk, Z. \& Acemoglu, H. (2011). Saglik calisanlari icin arastirma ve pratik istatistik. Istanbul: Anadolu Ofset.

Altunisik, R., Coskun, R. Bayraktaroglu, S., \& Yildirim, E. (2010). Sosyal bilimlerde arastirma yontemleri: SPSS uygulamali. Sakarya: Sakarya Yayincilik.

Armutlulu, I. H. (2008). Isletmelerde uygulamalı istatistik. Istanbul: Alfa.

Azuma, R., Baillot, Y., Behringer, R., Feiner, S. K., Julier, S., \& Macintyre, B. (2001). Recent advances in augmented reality. IEEE Computer Graphics and Applications, 21(6), 34-47.

Balci, A. (2006). Sosyal bilimlerde arastirma: Yontem, teknik ve ilkeler. Ankara: PegemA.

Basturk, R. (2011). Non-parametrik istatistiksel yontemler. Ankara: Ani.

Batdi, V. (2017). Egitlence uygulamalarinin akademik basariya etkisi: Meta-analitik bir calisma. Gazi Universitesi Egitim Fakultesi Dergisi, 37(1), 47-62.

Bekleyen, N. \& Yilmaz, A. (2012). Language learning strategies and mobile learning. In D. Koksal (Ed.), Proceedings book of the 7th International ELT Research Conference: Philosophical perspectives in ELT research (pp. 161-170). Ankara: Nobel.

Bujak, K. R., Radu, I., Catrambone, R., MacIntyre, B., Zheng, R., \& Golubsk, G. (2013). A psychological perspective on augmented reality in the mathematics classroom. Computers \& Education, 68, 536-544.

Buyukozturk, S., Cokluk, O., \& Koklu, N. (2013). Sosyal bilimler icin istatistik. Ankara: PegemA.

Buyukozturk, S. (2007). Deneysel desenler, ontest-sontest kontrol grubu desen ve veri analizi. Ankara: PegemA.

Chang, R. C., Chung, L. Y., \& Huang, Y. M. (2016). Developing an interactive augmented reality system as a complement to plant education and comparing its effectiveness with video learning. Interactive Learning Environments, 24(6), 1245-1264.

Cakir, R., Solak, E., \& Tan, S. S. (2015). Artirilmis gerceklik teknolojisi ile Ingilizce kelime ogretiminin ogrenci performansina etkisi. Gazi Egitim Bilimleri Dergisi, 1(1), 45-58. 
Cetinkaya, H. H. \& Akcay, M. (2013). Egitim ortamlarinda arttirilmis gerçeklik uygulamalari. XV. Akademik Bilisim Konferansi Bildirileri (ss. 1031-1035). Antalya: Akdeniz Universitesi.

Cil, B. (2008). Istatistik. Ankara: Detay.

Demirer, V. \& Erbas, C. (2015). Mobil artirilmis gerceklik uygulamalarinin incelenmesi ve egitimsel acidan degerlendirilmesi. Mersin Universitesi Egitim Fakultesi Dergisi, 11(3), 802-814.

De Winter, J. C. F. (2013). Using the Student's t-test with extremely small sample sizes. Practical Assessment Research \& Evaluation, 18(10), 1-12.

El Sayed, N. A., Zayed, H. H., \& Sharawy, M. I. (2011). ARSC: Augmented reality student card An augmented reality solution for the education field. Computers \& Education, 56(4), 1045-1061.

Ibili, E. \& Sahin, S. (2013). Artirilmis gerceklik ile interaktif 3D geometri kitabi yaziliminin tasarimi ve gelistirilmesi: ARGE3D. Afyon Kocatepe Universitesi Fen ve Muhendislik Bilimleri Dergisi, 13(1), 1-8, 2013.

Icten, T. \& Bal, G. (2017). Artirilmis gerceklik teknolojisi uzerine yapilan akademik calismalarin icerik analizi. Bilisim Teknolojileri Dergisi, 10(4), 401-415.

Juan, C. M., Llop, E., \& Abad, F. (2010). Learning words using augmented reality. Advanced Learning Technologies (ICALT), 2010 IEEE 10th International Conference on, (ss. 422426).

Karasar, N. (2003). Bilimsel arastirma yontemi. (12. baski). Ankara: Nobel.

Kartal, M. (2006). Bilimsel arastirmalarda hipotez testleri. Ankara: Nobel.

Klopfer, E. \& Squire, K. (2008). Environmental detectives - The development of an augmented reality platform for environmental simulations. Educational Technology Research and Development, 56(2), 203-228.

Kukulska-Hulme, A. \& Shield, L. (2008). An overview of mobile assisted language learning: From content delivery to supported collaboration and interaction. ReCALL, 20(3), 271-289.

Kutu, H. \& Sozbilir, M. (2011). Ogretim materyalleri motivasyon anketinin Turkceye uyarlanmasi: Guvenirlik ve gecerlik calismasi. Necatibey Egitim Fakultesi Elektronik Fen ve Matematik Egitimi Dergisi, 5(1), 292-312.

Kucuk, S., Yilmaz, R., \& Goktas, Y. (2014). Ingilizce ogreniminde artirilmis gerçeklik: Ogrencilerin basari, tutum ve bilissel yuk duzeyleri. Egitim ve Bilim, 39(176), 393-404.

Levine, D. M., Ramsey, P. P., \& Smidt, R. K. (2001). Applied statistics for engineers and scientists. Upper Saddle, NJ: Prentice Hall.

Liu, T.-Y., Tan, T. H., \& Chu, Y.L. (2010). QR code and augmented reality-supported mobile English learning system. In X. Jiang, M. Y. Ma, \& C. W. Chen (Eds.), Mobile multimedia processing (pp. 37-529. Berlin Heidelberg: Springer.

Mahadzi, N. \& Phung, L. (2013). The use of augmented reality pop-up book to increase motivation in English language learning for national primary school. Journal of Research \& Method in Education, 1(1), 26-38.

Ozcan, M. F., Ozkan, A., \& Sahin, N. (2017). The influence of the augmented reality application on students' performances in Ottoman Turkish readings. Universal Journal of Educational Research, 5(12), 27-33. 
Ozdamar, K. (2003). SPSS ile biyoistatistik. Eskisehir: Kaan Kitabevi.

Ozdamar, K. (2002). Paket programlar ile istatistiksel veri analizi. Eskisehir: Kaan Kitabevi.

Ozdemir, M. (2017). Artirilmis gerceklik teknolojisi ile ogrenmeye yonelik deneysel calismalar: Sistematik bir inceleme. Mersin University Journal of the Faculty of Education, 13(2), 609-632.

Ozdemir, M., Cavus, S., Arcagok, S., \& Demir, M. (2018). The effect of augmented reality applications in the learning process: A metaanalysis study. Eurasian Journal of Educational Research, 74, 165-186.

Pérez-López, D. \& Contero, M. (2013). Delivering educational multimedia contents through an augmented reality application: A case study on its impact on knowledge acquisition and retention. The Turkish Online Journal of Educational Technology, 12(4), 19-28.

Pallant, J. (2016). SPSS survival manual. Philadelphia: Open University Press.

Polatcan, F. (2015). Turkce ogretmeni adaylarinin bilgisayar kullanimina iliskin tutum ve gorusleri. Mustafa Kemal Universitesi Sosyal Bilimler Enstitusu Dergisi, 12(32), 388-400.

Sarikaya, M. (2015). Artirilmis gerceklik uygulamalarinin ogrencilerin akademik basarilari, kavram yanilgilari ve derse katilimlarina etkisi (Yayimlanmamis doktora tezi). Gazi Universitesi, Ankara.

Shelton, B. E. \& Hedley, N. R. (2004). Exploring a cognitive basis for learning spatial relationships with augmented reality. Technology, Instruction, Cognition and Learning, 1, 323-357.

Tulu, M. \& Yilmaz, M. (2012). iPhone ile artirilmis gerceklik uygulamalarinin egitim alaninda kullanilmasi. Akademik Bilisim Kongresi, Usak Universitesi.

Wu, H.K., Lee, S.Y., Chang, H.Y., \& Liang, J.C. (2013). Current status, opportunities and challenges of augmented reality in education. Computers \& Education, 62, 41-49.

Yilmaz, Z. A. \& Batdi, V. (2016). Artirilmis gerceklik uygulamalarinin egitimle butunlestirilmesinin meta-analitik ve tematik karsilastirmali analizi. Egitim ve Bilim, 41(188), 273-289.

Correspondence: Nurullah Sahin, Assistant Professor, Department of Turkish and Social Sciences Education, Faculty of Education, Sinop University, Sinop, Turkey 